\title{
Clinico-Therapeutic Management of Ketosis in a Cow
}

\author{
Sandhya Morwal* and Shantanu Kumar Kuldeep \\ College of Veterinary and Animal Science, Udaipur, India
}

*Corresponding author: Sandhya Morwal, Department of Veterinary Medicine (VCC),

College of Veterinary and Animal Science, Navania, Vallabhnagar, Udaipur, Rajasthan 313601, India, Email: sandhyamorwal@gmail.com

\section{Case Report}

Volume 2 Issue 2

Received Date: December 28, 2018

Published Date: March 08, 2019

DOI: $10.23880 /$ izab-16000139

\section{Abstract}

The clinical case study was carried out in a cow having sign of ketosis, diagnosis based on owner history, clinical symptoms and laboratory findings (Urine and blood sample). Therapeutic management was carried out as per physiological conditions of animal. Cow was treated with Injection of dextrose, corticosteroid, vitamin B-complex parental along with oral gluconeogenic precursors and jaggery. Case was treated successfully and excellent recovery.

Keywords: Cow; Ketosis; Rothera's Test; Therapeutic Management

\section{Introduction}

Ketosis is a metabolic disorder in dairy animals caused by impaired metabolism of carbohydrate and volatile fatty acids leading to excessive production of ketone bodies like Acetone, Acetoacetate and Beta-hydroxybutyrate. Ketosis a multi factorial disorder of energy metabolism leads to hypoglycemia and hyperketonemia [1,2]. During gestation period increase the demand of energy due to the foetal growth, lactogenesis and the early lactation is accompanied by a restricted feed intake which puts the animal in negative energy balance [3]. Excessive negative energy makes animal more susceptible to ketosis [4]. Ketosis can be diagnosed by measuring ketone bodies in urine, milk and blood. This clinical paper discussion a case of ketosis in a cow, diagnosed the case and treated successfully.

\section{Case History}

A six year old Holstein Friesians cow, in 3rd lactation $300 \mathrm{~kg}$ body weight, calved ten days ago. According to owner history cow was high yielder and during parturition she was suffering from dystocia and fetus removed manually. Milk production was reduced twelve liters to four liters since last three to four days; gradually signs of inappetance and now cow refuse grain feed and often pick at poor hay or straw bedding. Cow has a typical sweetish smell to the breath, urine and milk after parturition. Cow showed the head pressing, excessive licking of body and other object and muscle twitching.

\section{Clinical Finding}

During clinical examination observed that animal was dull and depressed, rectal temperature was $103^{\circ} \mathrm{F}$, respiration rate $45 / \mathrm{min}$, pulse rate was $60 / \mathrm{min}$ found slightly increased according to [5]. Ruminal movement was $1 / \mathrm{min}$. Cow has a typical acetone smell in the breath, urine and milk. On per rectal examination dry, mucoid and scanty faces were found.

\section{Diagnosis and Methodology}

Urine, Faecal and blood sample were collected and Rothera's test was carried out for presence of ketone bodies in urine and blood glucose level was also estimated. Urine sample was collected in clean dry glass tube and carried Rother's test, sample showed purple colour immediately after adding rother's powder, indicated the presence of ketone bodies in urine. Blood sample was examined for blood glucose level that was $30 \mathrm{mg} / \mathrm{dl}$ (Normal blood glucose level $44 \mathrm{mg} / \mathrm{dl}$ ) comparatively less [6,7]. Serum calcium level was found normal in laboratory tests. Fecal sample was carried out for the parasitic eggs/ ova by flotation and sedimentation technique but not revealed any parasitic and 
haemoprotozoan infection. The case was nervous form of ketosis according to owner's history, clinical signs and lab diagnosis.

\section{Results and Discussion}

Cow was immediately treated with $500 \mathrm{ml}$ of $50 \%$ dextrose injection, intravenously, as immediately energy source and continues for next three days. Dextrose suppresses the NEFA (non-esterified fatty acids) release and hepatic ketogenesis with in few hours and its beneficial for patients. Injection vetlog (Triamcinolone) $5 \mathrm{ml}$ intramuscular was injected. Glucocorticoids reduce ketone body formation by utilization of Acetyle CoA and raising blood glucose level by making greater availability of glucose precursor in the liver [6]. Injection liver extract with B-complex (Belamyl) $10 \mathrm{ml}$ intramuscular once in a day for five days was given as supportive therapy. Injection Neurokind, intravenously for 3 days, which help to overcome the nervous signs, Jaggery $100 \mathrm{gm}$ feeding was also recommended for five days as an instant source of energy. Powder Himalya Bithsa 50gm orally, twice in a day for 5 days. Two Bolus of Rumentas, twice in a day for next ten days also advised to owner for improving appetite and feeding of animal. Animal showed good response to second day of treatment and case was recovered successfully after 3 days treatment. Most commonly ketosis occurs in high milk producing buffaloes and crossbred cow during 3rd and 4th lactation period. Similar finding were reported by [8-10].

\section{Conclusion}

In the life of cow postpartum period is most critical time in which she becomes more susceptible to ketosis and other health problems. In this case the animal was suffering from primary ketosis sign plus some nervous signs. To cover the energy deficiency cow body use the reserved lipid and protein resulting liver produce more ketone bodies and excreted in urine and milk.

\section{References}

1. Radostits OM, Gay CC, Blood DC, Hinchcliff KW (2000) Veterinary Medicine. $9^{\text {th }}(\mathrm{Edn}$.), W B Saunders, London.

2. Radostits OM, Gay CC, Hinchcliff K, Constable PD (2010) Veterinary Medicine: A textbook of the Diseases of Cattle, Horse, Sheep, Pig and Goats, 10 ${ }^{\text {th }}$ (Edn.), Saunders Elsevier, Philadephia, PA.

3. Jorritsma R, Wensing T, Kruip TA, Vos PL, Noordhuizen JP (2003) Metabolic changes in early lactation and impaired reproductive performance in dairy cows. Vet Res 34(1): 11-26.

4. Rukkwamsuk T, Kruip TA, Wensing T (1999) Relationship between overfeeding and over conditioning in the dry period and the problem of high producing dairy cows during the past parturient period. Vet Quaterlt 21(3): 71-77.

5. Radostits OM, Gay CC, Blood DC, Hinchcliff KW (2006) Veterinary Medicine. $9^{\text {th }}(\mathrm{Edn}$.), W B Saunders, London.

6. Chakrabarti A (2006) Textbook of clinical Veterinary Medicine. $3^{\text {rd }}$ (Edn.), Kalyani Publishers, New Delhi.

7. Radostits OM, CC Gay, KW Hinchcliff, PD Constable (2007) Diseases of the alimentary tract. In: Radostits OM, Gay CC, Hinchcliff KW, Constable PD, (Eds.), Veterinary Medicine: A Textbook of the Diseases of Cattle, Horses, Sheep, Pigs and Goats. $10^{\text {th }}$ (Edn.), Saunders Elsevier.

8. Teli SA, Ali SL, Ray S, Kumar A (2013) Clinicoepidemiological study on bubaline ketosis in chhatishgarh. Indian J Vet Med 33: 46.

9. Tufani NA, Hafiz A, Muhee A, Makhdoomi DM (2011) Therapeutic management of ketosis in bovine. Indian J Vet Med 31: 38-39.

10. Andersson L, Gustafasson AH, Emanuelson U (1991) Effect of hyperketonemia and feeding on fertility in dairy cows. Theriogenology 36(4): 521-536. 